\title{
Pengaruh Brand Image dan Sikap Konsumen Terhadap Ekuitas Merek Pada Produk Ija Kroeng di Kota Banda Aceh
}

\author{
Rahmi $^{* 1}$, Nelly $^{1}$ \\ ${ }^{1}$ Fakultas Ekonomi Manajemen, Universitas Serambi Mekkah, Banda Aceh, 23249, Indonesia. \\ *Email korespondensi: rahmi@serambimekkah.ac.id ${ }^{1}$
}

Diterima 19 Juli 2018; Disetujui 11 September 2018; Dipublikasi 31 Oktober 2018

\begin{abstract}
Brand image and consumer attitudes are important factors in influencing brand equity. Brand equity is the value of a brand, depend the extent to which the brand has high loyalty, the quality that is accepted by consumers and able to add more value to consumers. A strong brand equity can help a company in an effort to attract potential customers as well as efforts to establish good relationships with consumers and can eliminate consumer doubts about brand quality. This study was aimed to determine The Influence Of Brand Image And Consumer Attitudes Toward Brand Equity In Ija Kroeng Products In Banda Aceh. The sample of this study was 100 respondents. The data used in this study was quantitative data. The results showed that brand image and consumer attitudes had a significant effect on brand equity in Ija Kroeng products in Banda Aceh, it was proven by the brand image and attitude of consumers as factors that influence brand equity, which was proven by $84.9 \%$ of research results and the remaining $15.1 \%$ explained by other variables outside of this research, for instance product quality, brand awareness, brand associations, etc. Statistical test results show that simultan brand image and consumer attitudes have a significan effect on brand equity in Ija Kroeng products in Banda Aceh, Fcount>Ftable (272.719>3,090). While partially brand image and consumer attitudes have a significant effect on brand equity in Ija Kroeng products in Banda Aceh, with the value of tcount>ttable (11,871 and 2,051>1,984). Based on the results of multiple linear regression it can be seen that of the two variables that the brand image (X1) had the most dominant influence on brand equity in Ija Kroeng products in Banda Aceh, with a coefficient value of 0,805, and the followed by the variable attitudes of consumers (X2) with a coefficient value of 0,139.
\end{abstract}

Keywords: Brand Image, Consumer Attitudes, Brand Equity.

\begin{abstract}
Abstrak: Brand image dan sikap konsumen merupakan faktor penting dalam mempengaruhi ekuitas merek, melalui merek yang kuat maka pelanggan akan memiliki asumsi positif terhadap suatu merek dari produk yang ditawarkan oleh perusahaan. Penelitian ini bertujuan untuk mengetahui pengaruh brand image dan sikap konsumen terhadap ekuitas merek pada produk Ija Kroeng di Kota Banda Aceh. Populasi dalam penelitian ini adalah konsumen yang menggunakan produk Ija Kroeng di Kota Banda Aceh. Sampel dalam penelitian ini berjumlah 100 responden.Data yang digunakan dalam penelitian ini adalah data kuantitatif. Hasil penelitian menunjukkan bahwa brand image dan sikap konsumen berpengaruh signifikan terhadap ekuitas merek pada produk Ija Kroeng di Kota Banda Aceh, hal ini dibuktikan bahwa brand image dan sikap konsumen merupakan faktor yang berpengaruh terhadap ekuitas merek, yang dibuktikan dengan hasil penelitian sebesar $84,9 \%$ dan sisanya sebesar $15,1 \%$ dijelaskan oleh variabel lain diluar dari pada penelitian ini, misalkan kualitas produk, kesadaran merek, asosiasi merek dan lain-lain. Hasil pengujian statistik menunjukkan bahwa secara simultan brand image dan sikap konsumen berpengaruh signifikan terhadap ekuitas merek pada produk Ija Kroeng di Kota Banda Aceh, dengan nilai Fhitung>Ftabel (272.719>3,090). Sedangkan secara parsial brand image dan sikap konsumen berpengaruh signifikan terhadap ekuitas merek pada produk Ija Kroeng di Kota Banda Aceh, dengan nilai thitung>ttabel (11,871 dan 2,051>1,984).
\end{abstract}


Berdasarkan hasil analisis regresi linier berganda dapat diketahui bahwa dari kedua variabel yang diteliti, ternyata variabel brand image (X1) berpengaruh paling dominan terhadap ekuitas merek pada produk Ija Kroeng di Kota Banda Aceh, dengan nilai koefisien sebesar 0,805, dan selanjutnya diikuti oleh variabel sikap konsumen (X2) dengan nilai koefisien sebesar 0,139.

\section{Kata kunci : brand image, sikap konsumen, ekuitas merek}

Fashion menjadi bagian yang sangat penting dari penampilan dan gaya hidup masyarakat, bendabenda seperti baju, dan asesoris yang digunakan bukanlah sekedar penutup tubuh dan hiasan, lebih dari itu juga menjadi sebuah alat komunikasi untuk menyampaikan identitas pribadi. Banyak produk yang ditawarkan dengan berbagai jenis merek. Merek dapat menambah keyakinan konsumen untuk membeli suatu produk, dan menjadi penilaian penting bagi konsumen sebelum membeli suatu produk. Karena bagi konsumen, mendapatkan sebuah produk yang berkualitas tinggi dengan merek yang sudah dikenal oleh masyarakat luas, maka akan mendorong konsumen untuk menjadi bagian dari asosiasi merek tersebut. karena jika konsumen sudah merasa puas dengan suatu produk maka, mereka tidak akan segan untuk membayar lebih mahal agar dapat memperoleh produk dengan merek tertentu. Karena sudah tentu ada jaminan konsistensi kualitas dan nilai tertentu yang diyakini akan diterima oleh konsumen, dengan adanya merek konsumen akan merasa lebih aman dari kemungkinan buruk yang akan diterima jika produk yang mereka beli tidak sesuai dengan harapan. "Ekuitas merek adalah nilai dari suatu merek, menurut sejauh mana merek itu mempunyai loyalitas yang tinggi, kesadaran nama, kualitas yang diterima, asosiasi merek yang kuat, serta asset lain seperti paten merek dagang, dan hubungan saluran (Kotler dan Amstrong, 2009:357)". Sedangkan "merek merupakan identitas sebuah produk yang dapat dijadikan sebagai alat ukur apakah produk itu baik dan berkualitas. Konsumen melihat sebuah merek sebagai bagian yang paling penting dalam sebuah produk, dan merek dapat menjadi sebuah nilai tambah dalam produk tersebut (Kotler, 2009:285)".

Ada beberapa faktor yang mempengaruhi ekuitas merek, yaitu brand image. "Brand image adalah persepsi yang bertahan lama, dibentuk melalui pengalaman, dan bersifat relatif konsisten (Schifman dan Kanuk, 2010:213)”. Dengan adanya brand image maka konsumen dapat mengasumsikan bahwa produk yang ditawarkan akan sesuai dengan harapan mereka, sehingga konsumen tidak akan merasa ragu untuk menggunakan produk tersebut. Citra merek sangat penting untuk diperhatikan oleh sebuah perusahaan, karena dengan adanya citra merek yang baik, tentu saja akan mendapatkan penilaian positif dari konsumen, dan dapat mendorong konsumen untuk membeli dan menggunakan produk tersebut. karena citra mereka merupakan kepercayaan konsumen terhadap suatu merek tertentu, dan asosiasi merek tersebut dapat terus melekat dalam benak konsumen.

Sikap konsumen juga dapat mempengaruhi ekuitas merek. Dalam proses pengambilan keputusan, sikap merupakan variabel pemikiran konsumen, selain adanya faktor kebutuhan. Oleh karena itu, sangat penting untuk dapat memahami sikap konsumen terhadap suatu merek produk. Agar 
dapat mengetahui pentingnya posisi merek dimata konsumen.

Kain sarung bagi masyarakat Aceh adalah kebutuhan. Tidak ada masyarakat Aceh yang tidak memilikinya, kain sarung dapat digunakan untuk solat, mengaji, ada juga masyarakat yang kesehariannya memakai sarung di dirumah, bahkan dalam seserahan asoe talam pengantin selalu menyertakan kain sarung didalamnya. Kebiasankebiasaan orang Aceh inilah yang kemudian menginspirasi Khairul Fahri Yahya atau biasa disapa Cek Loe sebagai pencetus Ija Kroeng untuk membuat usaha kain sarung merek Ija Kroeng. Ija Kroeng memiliki beragam motif pilihan, yang mengangkat ciri khas Aceh, seperti motif pinto Aceh, kerawang gayo, gagang rencong dan cap sikureung. Hitam dan putih adalah warna original produk Ija Kroeng, namun juga terdapat warna spesial lainnya dengan tergantung selera konsumen, karena setiap tahun selalu dihadirkan motif dan desain yang unik dengan pilihan warna yang lebih bervariasi, agar konsumen dapat menentukan motif dan warna apa saja yang cocok untuk digunakan. Untuk ukuran juga disiapkan bagi dewasa dan anak-anak. Selama ini kain sarung identik dengan motif kotak-kotak atau garis-garis, dan dengan munculnya produk Ija Kroeng ini, ingin memperkenalkan dengan desain yang berbeda, unik, trendi dan modern, sehingga dapat digunakan oleh setiap orang dari kalangan manapun, dari yang muda sampai orang tua pun akan merasa puas dan nyaman dalam memakai kain sarung dengan merek Ija Kroeng.

\section{KAJIAN PUSTAKA}

\section{Brand Image}

Menurut Kotler (2009:346) "brand image (citra merek) adalah persepsi dan keyakinan yang di lakukan oleh konsumen seperti yang terkandung dalam asosiasi yang terjadi dalam memori konsumen". Sedangkan menurut "Schifman dan Kanuk (2010:213) brand image adalah persepsi yang bertahan lama, dibentuk melalui pengalaman, dan bersifat relatif konsisten". Sedangkan "Keller dalam Ferrinadewi (2009:23) mengatakan brand image adalah persepsi tentang brand yang merupakan refleksi memori konsumen akan asosiasinya pada brand tersebut".

Menurut Rangkuti (2009:244) "brand image adalah sekumpulan asosiasi merek yang terbentuk dan melekat dibenak konsumen”. Menurut Rangkuti (2009:83) adapun manfaat brand image antara lain adalah:

1. Konsumen dengan citra yang positif terhadap suatu merek, lebih memungkinkan untuk melakukan pembelian.

2. Pengembangan lini produk dapat dilakukan oleh Perusahaan dengan memanfaatkan citra positif dari merek produk sebelumnya.

Menurut Rangkuti (2009:83) adapun brand image yang efektif memiliki dua hal :

1. Menetapkan karakter produk dan usulan nilai

2. Menyajikan ciri atau karakter produk dengan design berbeda dengan pesaingnya.

\section{Faktor-Faktor Yang Mempengaruhi Brand Image}

Menurut Keller dalam Ferrina Dewi (2009:24) faktor-faktor pendukung terbentuknya brand image antara lain: 
1. "Keunggulan asosiasi merek (favorability of brand association)". Dengan adanya hal tersebut, maka akan meyakinkan konsumen tentang manfaat yang akan didapatkan dari sebuah brand, dan tentu saja akan dapat memberikan kepuasan kepada konsumen, dan pada akhirnya akan memunculkan sikap positif terhadap brand tersebut.

2. "Kekuatan asosiasi merek (strenght of brand association)". Untuk Hal ini harus dapat mengupayakan agar informasi dapat masuk dalam benak konsumen, sehingga informasi tersebut dapat dikelola oleh data sensoris di otak sebagai bagian dari brand image.

3. "Keunikan asosiasi merek (uniqueness of brand association)". Suatu brand itu harus unik, menarik dan dan memiliki cirri yang khas dan tidak mudah ditiru oleh pesaing lain.

Menurut Schiffman dan Kanuk (2010:285) menyebutkan faktor-faktor pembentuk brand image adalah sebagai berikut:

1. Berkaitan dengan kualitas Produk yang ditawarkan oleh produsen dengan merek tertentu

2. Dapat dipercaya atau diandalkan, berkaitan dengan pendapat atau kesepakatan yang dibentuk oleh masyarakat tentang suatu produkyang dikonsumsi.

3. Manfaat produk, hal ini berkaitan dengan fungsi dari sebuah produk yang nantinya dapat dimanfaatkan oleh konsumen.

4. Pelayanan, produsen harus dapat melayani konsuemnya dengan baik.
5. Resiko, hal ini berkaitan dengan akibat yang akan didapatkan, untung dan rugi yang mungkin saja dapat dialami oleh konsumen.

6. Harga, berkaitan dengan tinggi rendahnya atau banyak sedikitnya jumlah uang yang dikeluarkan konsumen untuk memperoleh sebuah produk dapat mempengaruhi citra dalam waktu yang lama.

7. Nilai positif atau citra merek pada suatu produk, dapat berupa pandangan, kesepakatan dan informasi yang berkaitan erat dengan ssebuah brand dari produk tertentu.

\section{Sikap Konsumen}

Menurut Nugroho (2008:214) „sikap konsumen yaitu mempelajari kecendrungan konsumen untuk mengevaluasi merek baik yang disenangi ataupun tidak disenangi secara konsisten". Menurut Sumarwan (2009:137) sikap adalah gambaran perasaan dari seseorang konsumen, dan perasaan tersebut akan direfleksikan oleh perilakunya“. Menurut Sutisna (2008:99) „sikap adalah mempelajari kecenderungan memberikan tanggapan pada suatu obyek atau kelompok obyek baik disenangi atau tidak disenangi secara konsisten". Menurut Gordon Allport dalam Nugroho (2008:214) "sikap adalah suatu mental dan syaraf sehubungan dengan kesiapan untuk menanggapi, diorganisasi melalui pengalaman dan memiliki pengaruh yang mengarahkan dan atau dinamis terhadap perilaku“.

\section{Komponen Sikap konsumen Atas Merek}

Menurut Sumarwan

(2009:82) mengungkapkan bahwa terdapat beberapa model 
sikap konsumen atas merek antara lain, yaitu:

1. The tricomponent attitude model (Triandis). Sikap konsumen atas sebuah produk terbentuk dari tiga komponen antara lain: kepercayaan (kognitif), emosi (afektif), dan keinginan berperilaku (konatif).

2. Multi attribute attitude model (Fishbein). Model multiatribut menjelaskan konsumen akan menilai suatu model sikap (terhadap produk atau merek) besar pengaruhnya oleh sikap konsumen terhadap atribut-atribut yang dievaluasi. .

3. Ideal point model (model angka-ideal). Pada model angka ideal ini memberikan informasi tentang sikap konsumen terhadap suatu merek produk dan juga berkaitan dengan merek yang ideal yang dirasakan oleh konsumen.

Menurut Simamora (2008:157) sikap atas merek memiliki empat fungsi antara lain, yaitu:

1. Fungsi penyesuaian

2. Fungsi pertahanan ego

3. Fungsi ekspresi nilai

4. Fungsi pengetahuan

Faktor-Faktor Yang Mempengaruhi Sikap konsumen Atas Merek

Menurut Kotler dan Keller (2009:57) adapun faktor-faktor yang mempengaruhi sikap konsumen atas merek itu sendiri yaitu sebagai berikut:

1. Faktor Sosial

a. Group (kelompok acuan)

b. Family Influence (pengaruh keluarga)

c. Roles and Status (peran dan status)

2. Faktor Personal

a. Economic Situation (situasi ekonomi) b. Lifestyle (gaya hidup)

c. Personality and Self Concept (kepribadian dan konsep diri)

d. "Age and Life Cycle (umur dan siklus hidup)"

e. Occupation (pekerjaan)

3. Faktor Psikologi

a. Motivation (motivasi)

b. Perception(persepsi)

c. Learning(pmbelajaran)

d. Beliefs and Attitude (kepercayaan dan sikap)

4. Faktor Kebudayaan
a. Subculture (subkultur)
b. Social Class(kelas sosial)

\section{Ekuitas Merek}

Menurut Kotler (2009:86) "ekuitas merek (brand equity) adalah sebagai efek diferensial positif yang ditimbulkan oleh pengetahuan nama merek terhadap tanggapan pelanggan atas produk atau jasa tersebut”. Menurut Kotler dan Amstrong (2009:357) "menyebutkan ekuitas merek adalah nilai dari suatu merek, menurut sejauh mana merek itu mempunyai loyalitas yang tinggi, kesadaran nama, kualitas yang diterima, asosiai merek yang kuat, serta asset lain seperti paten merek dagang, dan hubungan saluran".

Menurut Kotler dan Keller (2009:334) "Ekuitas merek merupakan aset tak berwujud yang penting, yang memiliki nilai psikologis dan keuangan bagi perusahaan". Sedangkan Aaker dalam Kotler dan Keller (2009:339) "ekuitas merek adalah satu perangkat dari lima kategori aset dan liabilitas merek yang berkaitan dengan merek yang menambah atau mengurangi nilai yang diberikan sebuah produk atau jasa kepada perusahaan dan/atau pelanggan”. 
Menurut David Aaker dalam Tjiptono (2009:38) "ekuitas merek adalah serangkaian aset dan kewajiban merek yang terkait dengan sebuah merek, nama, dan simbolnya, yang menambah atau mengurangi nilai yang diberikan sebuah produk atau jasa kepada perusahaan dan atau pelanggan perusahaan tersebut".

\section{Faktor-Faktor Yang Mempengaruhi Ekuitas}

\section{Merek}

Menurut Aaker dalam Tjiptono (2009:38) yaitu bahwa terdapat lima faktor pada ekuitas merek, yaitu:

1. “Kesadaran merek (brand awareness) merupakan elemen ekuitas yang sangat penting bagi perusahaan karena kesadaran merek dapat berpengaruh secara langsung terhadap ekuitas merek".

2. "Asosiasi merek (brand associations) sebagai segala sesuatu yang terhubung di memori konsumen terhadap suatu merek".

3. "Mutu yang dirasakan (perceived quality) persepsi konsumen terhadap kualitas atau keunggulan suatu produk atau jasa sehubungan dengan tujuan yang diinginkannya, dibandingkan dengan alternatif-alternatif lain".

4. "Loyalitas merek (brand loyalty) adalah sebuah ukuran ketertarikan konsumen terhadap suatu merek".

5. "Aset-aset lain yang berkaitan dengan merek (other brand-related assets)".

\section{METODOLOGI PENELITIAN}

\section{Lokasi dan Subjek Penelitian}

Penelitian ini dilaksanakan di Workshop Ija Kroeng yang beralamat di Jalan Teuku Umar Lr. Mahya No. 51, Setui Kota Banda Aceh. Penelitian ini akan membahas mengenai pengaruh brand image dan sikap konsumen terhadap ekuitas merek pada produk Ija Kroeng di Kota Banda Aceh. Pembahasan dari penelitian ini hanya terbatas pada masalah pengaruh brand image dan sikap konsumen terhadap ekuitas merek pada produk Ija Kroeng di Kota Banda Aceh. Dalam hal ini produk Ija Kroeng yang dimaksud yaitu produk berupa kain sarung yang merupakan kreasi dari anak muda Aceh yang didesain unik dengan ciri khas Aceh seperti motif Pinto Aceh, motif Kerawang Gayo, Motif gagang rencong dan motif cap Sikureueng, trendi dan modern, nyaman untuk digunakan oleh anak-anak dan dewasa.

Jenis data yang digunakan adalah data primer dan data sekunder. Dalam penelitian ini responden nya adalah konsumen Ija Kroeng yang ada di Kota Banda Aceh. Jumlah responden yang diambil sebagai sampel yaitu 100 responden dengan menggunakan teknik convinience sampling.

"Untuk melakukan pengujian dalam penelitian ini digunakan jenis pengujian regresi linear berganda untuk menaksir bagaimana keadaan (naik turunnya) variabel dependen, bila dua atau lebih variabel dependen sebagai faktor predictor dimanipulasi (dinaik turunkan nilainya) (Sugiyono, 2012:277)". Bila dijabarkan secara matematis bentuk persamaan dari regresi linier berganda adalah sebagai berikut:

$$
Y=a+b_{1} X_{1}+b_{2} X_{2}+e
$$


Di mana :

$\begin{array}{ll}\mathrm{Y} & =\text { Ekuitas Merek } \\ \alpha & =\text { Konstanta } \\ \mathrm{X}_{1} & =\text { Brand Image } \\ \mathrm{X}_{2} & =\text { Sikap konsumen } \\ \mathrm{b}_{1} \text { dan } \mathrm{b}_{2} & =\text { Koefisien regresi } \mathrm{X}_{1} \text { dan } \mathrm{X}_{2} \\ e & =\text { Error term }\end{array}$

\section{HASIL DAN PEMBAHASAN}

\section{Gambaran umum Ija Kroeng}

Kearifan lokal berkain sarung telah dikenal luas semenjak zaman kerajaan Aceh Darussalam pada abad ke-17. Kain serba guna yang dapat dimanfaatkan oleh masyarakat untuk berbagai kesempatan itupun menjadi pakaian lintas kasta, usia dan gender. Budaya berkain sarung pada masyarakat Aceh sudah dikenal sejak masa-masa kanak-kanak oleh Cek Loe (Khairul Fajri Yahya), karena hampir setiap hari nya anak-anak yang mengaji di Mesjid atau tempat pengajian lainnya menggunakan kain sarung. Selain menemani dalam keseharian masyarakat Aceh, kain sarung juga hadir dalam setiap acara istimewa seperti menjadi pelengkap pada pakaian adat dan menjadi salah satu isi hantaran yang wajib di sediakan pada prosesi pernikahan masyarakat Aceh.

Menurut Cek Loe cerita sehelai kain sarung atau dalam bahasa lokal disebut Ija Kroeng bukan sebatas pakaian, tapi merupakan identitas budaya. Awal mulanya lahir ide untuk memberikan nama merek Ija Kroeng adalah dalam keseharian masyarakat kata untuk menyebutkan kain sarung adalah Ija Kroeng. Dan selama ini memang jarang sekali nama sebuah produk digunakan sebagai nama merek, namun untuk Ija Kroeng, dalam masyarakat Aceh memang merupakan istilah yang sudah familiar bagi setiap masyarakatnya. Sehingga penggunaan nama ija kroeng diharapkan dapat dengan mudah dikenal oleh masyarakat, karena jika di Aceh, begitu orang menyebut nama ija kroeng, maka secara pasti semua orang akan paham bahwa itu adalah kain sarung. Produk Ija Kroeng secara resmi terdaftar pada bulan Maret 2015, hak cipta Ija Kroeng pun telah disahkan oleh HKI (Hak Kekayaan Intelektual).

Ija Kroeng diproduksi dari bahan katun 100\% berkualitas tinggi, yang didatangkan dari luar Aceh dan selain itu Ija Kroeng juga dibuat dengan "handmade". Termasuk dalam memberikan motif yang dilukis langsung dengan cat kain berkualitas dan tidak luntur. Sehingga setiap orang yang menggunakan produk Ija Kroeng, selalu merasa puas. Ada juga konsumen yang khusus memesan kain sarung untuk kebutuhan bulan ramadhan dan hari raya Idul Fitri. Karena biasa nya Workshop Ija Kroeng ini selalu menyediakan motif khusus setiap tahunnya untuk momen penting bagi masyarakat, seperti bulan ramadhan dan "hari raya Idul Fitri".

Awal nya Ija Kroeng diproduksi dengan motif polos, yaitu warna hitam dan putih. Kemudian seiring waktu dikembangkan lagi dengan motif kerawang Gayo pada bulan Oktober 2015, dengan motif lukis. Beberapa bulan kemudian proses permotifan kain sarung sudah menggunakan mesin print. Dan hari ini produk Ija Kroeng sudah diproduksi lebih modern dan dimodifikasi lebih indah lagi, misalnya dengan motif gagang rencong, motif pintu Aceh yang dimodifikasi, motif stempel raja (cap sikureueng), dan terus dikembangkan dalam berbagai macam motif khas Aceh yang unik.

Untuk pangsa pasar, Cek Loe masih fokus pada konsumen masyarakat Aceh. Karena di Aceh tidak ada masyarakat yang tidak punya kain sarung, dari pertimbangan ini lah, cek Loe bisa 
mengkalkulasikan kebutuhan kain sarung bagi masyarakat Aceh setiap tahunnya. Karena selama ini kebutuhan kain sarung di Aceh masih didatangkan dari luar Aceh. Untuk harga dibedakan pada jenis kualitas bahan yang digunakan, pemotifan, dan limited seri dari produk Ija Kroeng. Untuk warna original masih tetap warna hitam dan putih. Untuk menjaga kepercayaan konsumen,

Selama ini kain sarung identik dengan kotakkotak atau garis-garis, nah, hari ini Ija Kroeng ingin memperkenalkan dengan desain yang berbeda, trendi dan modern, sehingga dapat digunakan oleh setiap orang dari kalangan manapun, dari yang muda sampai orang tua pun akan merasa puas dan nyaman dalam memakai kain sarung dengan merek Ija Kroeng. Untuk produk lain juga sudah mulai diproduksi seperti tas, baju, scarf dll. Namun tetap fokus pada kain sarung. Dan untuk saat ini tujuan pemasaran dari produk Ija Kroeng ini hanya dibatasi untuk masyarakat Aceh, dan jika pun melebar keluar, itu merupakan dampak dari bocor nya informasi yang disampaikan antar satu konsumen dengan konsumen yang lainnya. Dan jika ada yang berminat untuk order, maka cek Loe tetap akan melayani permintaan konsumen dari luar.

\section{Analisis Pengaruh Brand Image Dan Sikap}

\section{Konsumen Terhadap Ekuitas Merek Pada}

\section{Produk Ija Kroeng Di Kota Banda Aceh}

Sesuai dengan peralatan analisis data yang digunakan untuk mengetahui hubungan fungsional antara variabel yang diteliti dalam penelitian ini, maka dianalisis dengan regresi linier berganda. Analisis hasil penelitian mengenai pengaruh brand image dan sikap konsumen terhadap ekuitas merek pada produk Ija Kroeng di Kota Banda Aceh. Hal ini ditunjukkan oleh nilai koefisien regresi masingmasing variabel seperti terlihat dalam Tabel 1 .

Tabel 1. Hasil Perhitungan Regresi MasingMasing Independen

\begin{tabular}{|c|c|c|c|c|c|c|c|}
\hline \multicolumn{8}{|c|}{ Coefficients $^{a}$} \\
\hline \multirow[b]{2}{*}{ Model } & \multicolumn{2}{|c|}{$\begin{array}{l}\text { Unstandardize } \\
\text { d Coefficients }\end{array}$} & \multirow{2}{*}{  } & \multirow[b]{2}{*}{$\mathrm{t}$} & \multirow[b]{2}{*}{ Sig. } & \multicolumn{2}{|c|}{$\begin{array}{l}\text { Collinearity } \\
\text { Statistics }\end{array}$} \\
\hline & B & $\begin{array}{l}\text { Std. } \\
\text { Error }\end{array}$ & & & & $\begin{array}{l}\text { Toleranc } \\
\text { e }\end{array}$ & VIF \\
\hline (Constant) & .915 & .950 & & 7.963 & .000 & & \\
\hline $\begin{array}{l}\text { Brand } \\
\text { Image }\end{array}$ & .802 & .068 & .805 & $\begin{array}{r}11.87 \\
1\end{array}$ & .000 & .339 & 2.953 \\
\hline $\begin{array}{l}\text { Sikap } \\
\text { konsumen }\end{array}$ & .157 & .076 & .139 & 2.051 & .043 & .339 & 2.953 \\
\hline $\begin{array}{l}\text { a. Dependen } \\
\text { Variable: Ek }\end{array}$ & $\mathrm{se}$ & & & & & & \\
\hline
\end{tabular}

Berdasarkan Tabel 1 maka persamaan regresi yang memperlihatkan ekuitas merek pada produk Ija Kroeng di Kota Banda Aceh sebagai fungsi brand image dan sikap konsumen dapat diformulasikan dalam persamaan sebagai berikut ini:

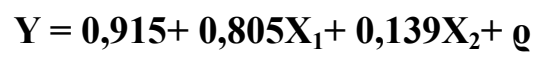

Dari persamaan regresi diatas dapat diketahui bahwa hasil penelitian sebagai berikut:

1. Konstanta sebesar 0,915 artinya jika brand image $\left(\mathrm{X}_{1}\right)$ dan sikap konsumen $\left(\mathrm{X}_{2}\right)$ dianggap konstan, maka besarnya ekuitas merek pada produk Ija Kroeng di Kota Banda Aceh adalah sebesar 0,915 pada satuan skala likert.

2. Koefisien regresi brand image $\left(\mathrm{X}_{1}\right)$ sebesar 0,805 , artinya bahwa setiap $100 \%$ perubahan dalam variabel brand image, maka secara relatif akan mempengaruhi ekuitas merek pada produk Ija Kroeng di Kota Banda Aceh sebesar $80,5 \%$ dengan demikian semakin tinggi pengaruh brand image 
akan semakin mempengaruhi ekuitas merek pada produk Ija Kroeng di Kota Banda Aceh.

3. Koefisien regresi sikap konsumen $\left(\mathrm{X}_{2}\right)$ sebesar 0,139 artinya bahwa setiap $100 \%$ perubahan dalam variabel sikap konsumen, maka secara relatif akan mempengaruhi ekuitas merek pada produk Ija Kroeng di Kota Banda Aceh sebesar 13,9\% dengan demikian semakin tinggi pengaruh sikap konsumen atas merek akan semakin mempengaruhi ekuitas merek pada produk Ija Kroeng di Kota Banda Aceh.

Berdasarkan hasil "analisis regresi linier berganda" dapat diketahui bahwa dari kedua variabel yang telah diteliti, ternyata variabel brand image $\left(\mathrm{X}_{1}\right)$ berpengaruh paling dominan terhadap ekuitas merek pada produk Ija Kroeng di Kota Banda Aceh, dengan nilai koefisien sebesar 0,805 , dan selanjutnya diikuti oleh variabel sikap konsumen $\left(\mathrm{X}_{2}\right)$ dengan nilai koefisien sebesar 0,139 .

\section{Pembuktian Hipotesis}

\section{Uji F (Simultan)}

Hasil pengujian statistik menunjukkan nilai $F_{\text {hitung }}$ sebesar 272.719 nilai $F_{\text {tabel }}$ pada tingkat keyakinan 95 persen menunjukkan angka sebesar 3,090. Karena nilai $F_{\text {hitung }}>F_{\text {tabel }} \quad(272.719>3,090)$ dapat diartikan secara simultan brand image $\left(\mathrm{X}_{1}\right)$, dan sikap konsumen $\left(\mathrm{X}_{2}\right)$ berpengaruh signifikan terhadap ekuitas merek pada produk Ija Kroeng di Kota Banda Aceh, sehingga Ha diterima.

\section{Uji t (Parsial)}

Uji t (parsial) dilakukan untuk mencari pengaruh variabel bebas terhadap variabel terikat dalam persamaan regresi secara parsial dengan mengasumsikan variabel lain dianggap konstan. Uji t dilakukan dengan membandingkan antara nilai $t_{\text {hitung }}$ dengan nilait tabel, yaitu:

1. Hipotesis pertama pada variabel brand image $\left(\mathrm{X}_{1}\right)$ menunjukkan nilai $\mathrm{t}_{\text {hitungnilai }}$ $\mathrm{t}_{\text {hitung }}>\mathrm{t}_{\text {tabel }} \quad(11,871>1,984)$, maka secara parsial brand image berpengaruh signifikan terhadap ekuitas merek pada produk Ija Kroeng di Kota Banda Aceh, sehingga hipotesis pertama Ha diterima.

2. Hipotesis kedua untuk variabel sikap konsumen $\left(\mathrm{X}_{2}\right)$ menunjukkan nilai $t_{\text {hitung }}>t_{\text {tabel }} \quad(2,051>1,984)$, maka secara parsial sikap konsumen berpengaruh signifikan terhadap ekuitas merek pada produk Ija Kroeng di Kota Banda Aceh, sehingga hipotesis kedua Ha diterima.

Untuk lebih jelasnya mengenai hasil uji $\mathrm{F}$ dan uji $\mathrm{t}$ sebagai tolak ukur pengujian hipotesis dapat dilihat Tabel 2.

Tabel 2. Ringkasan Pengujian Hipotesis

\begin{tabular}{|c|c|c|c|}
\hline \multirow{2}{*}{$\begin{array}{l}\text { Bentuk } \\
\text { Pengujian }\end{array}$} & \multicolumn{2}{|c|}{ Nilai Statistik } & \multirow{2}{*}{ Keterangan } \\
\hline & $\begin{array}{r}\mathrm{F} \\
\text { hitung }\end{array}$ & $\begin{array}{r}\mathrm{F} \\
\text { tabel }\end{array}$ & \\
\hline $\begin{array}{l}\text { Pengujian } \\
\text { secara } \\
\text { simultan }\end{array}$ & 272.719 & 3,090 & $\begin{array}{l}\text { Kedua } \\
\text { berpengaruh } \\
\text { signifikan (hipotesis } \\
\text { Ha diterima). }\end{array}$ \\
\hline $\begin{array}{l}\text { Pengujian } \\
\text { secara parsial }\end{array}$ & $\mathrm{t}_{\text {hitung }}$ & $\mathrm{t}_{\text {tabel }}$ & \\
\hline $\begin{array}{l}\text { Brand Image } \\
\left(\mathrm{X}_{1}\right)\end{array}$ & 11,871 & 1,984 & $\begin{array}{l}\text { Brand image } \\
\text { berpengaruh } \\
\text { signifikan }\end{array}$ \\
\hline $\begin{array}{l}\text { Sikap } \\
\text { konsumen } \\
\left(\mathrm{X}_{2}\right)\end{array}$ & 2,051 & 1,984 & $\begin{array}{l}\text { Sikap konsumen } \\
\text { berpengaruh } \\
\text { signifikan }\end{array}$ \\
\hline
\end{tabular}


Berdasarkan Tabel 2 diatas jelaslah bahwa baik secara simultan maupun secara parsial brand image dan sikap konsumen berpengaruh signifikan terhadap ekuitas merek pada produk Ija Kroeng di Kota Banda Aceh. Hal ini berarti bahwa brand image dan sikap konsumen secara nyata dapat meningkatkan ekuitas merek pada produk Ija Kroeng di Kota Banda Aceh.

\section{KESIMPULAN DAN SARAN}

\section{Kesimpulan}

Berdasarkan hasil penelitian yang telah peneliti lakukan, maka dapat diambil beberapa kesimpulan sebagai berikut:

Hasil uji statistik uji $\mathrm{F}$ menunjukkan bahwa nilai $F_{\text {hitung }}>F_{\text {tabel }}(272.719>3,090)$, artinya semakin tinggi pengaruh brand image dan sikap konsumen maka akan semakin mempengaruhi ekuitas merek pada produk Ija Kroeng di Kota Banda Aceh

Brand image berpengaruh terhadap ekuitas merek pada produk Ija Kroeng di Kota Banda Aceh, dengan nilai $t_{\text {hitung }}$ nilai $t_{\text {hitung }}>t_{\text {tabel }}(11,871>1,984)$. Hal ini menunjukan bahwa sikap positif yang ditunjukan oleh konsumen akan menciptakan brand image yang baik tentang produk Ija Kroeng sehingga ekuitas merek pada produk Ija Kroeng di Kota Banda Aceh akan meningkat.

Sikap konsumen berpengaruh terhadap ekuitas merek pada produk Ija Kroeng di Kota Banda Aceh, dengan nilai $t_{\text {hitung }}>t_{\text {tabel }}(2,051>1,984)$. Hal ini menunjukan bahwa sikap positif yang di tunjukan oleh konsumen pada sikap konsumen akan meningkatkan ekuitas merek pada produk Ija Kroeng di Kota Banda Aceh.

Hasil Koefisien korelasi (R) sebesar 0,921 yang menunjukkan bahwa derajat hubungan (korelasi) antara brand image dan sikap konsumen dengan ekuitas merek pada produk Ija Kroeng di Kota Banda Aceh sebesar 92,1\%.

Hasil koefisien determinasi $\left(\mathrm{R}^{2}\right)$ menunjukkan bahwa pengaruh brand image dan sikap konsumen terhadap ekuitas merek pada produk Ija Kroeng di Kota Banda Aceh sebesar 84,9\%. Sedangkan selebihnya sebesar $15,1 \%$ dijelaskan oleh variabel lain diluar dari pada penelitian ini misalkan kualitas produk, kesadaran merek, asosiasi merek dan lainlain.

\section{Saran}

Berdasarkan kesimpulan yang diperoleh dari hasil penelitian, beberapa saran yang diusulkan adalah:

1. Produk Ija Kroeng harus terus dipertahankan dan ditingkatkan, karena produk Ija Kroeng ini memiliki motif dan desain yang memperkenalkan produk khas dari Aceh, dan dalam waktu yang sama juga dapat meningkatkan brand image dan sikap konsumen dan memberikan pembelajaran yang baik dalam meningkatkan ekuitas merek pada produk Ija Kroeng di Kota Banda Aceh.

2. Pencetus produk Ija Kroeng dapat meningkatkan brand image dengan cara:

3. Meningkatkan kualitas produk agar tetap dapat bertahan dengan desain dan motif yang unik yang sudah menjadi ciri khas dari produk Ija Kroeng.

a. Melakukan inovasi terhadap kemasan produk agar dapat membuat konsumen tertarik untuk membeli produk Ija Kroeng.

b. Memberikan semua informasi terbaru kepada konsumen tentang desain dan motif Ija Kroeng yang terbaru. 
4. Pada penelitian selanjutnya penelitian yang telah kami lakukan ini, diharapkan juga menjadi bahan referensi pelengkap bagi penelitian yang akan dilakukanselanjutnya. dan peneliti selanjutnya agar dapat menambahkan beberapa variabel lain yang berpengaruh pada ekuitas merek seperti: kualitas produk, kesadaran merek, asosiasi merek dan lain-lain.

\section{DAFTAR PUSTAKA}

Durianto, Darmadi, Sugiarto, dan Tony Sitinjak. (2009). Strategi Menaklukan Pasar Melalui Riset Ekuitas dan Perilaku Merek. Jakarta: PT. Gramedia.

Ferrinadewi, Erna. (2009). Merek dan Psikologi Konsumen: Implikasi Pada Strategi Pemasaran. Yogyakarta: Graha Ilmu.

Kotler, Philip. (2009). Manajemen Pemasaran. Jakarta: Penerbit PT. Indeks.

Kotler, Philip dan Gery Amstrong. (2009).

$$
\begin{aligned}
& \text { Manajemen Pemasaran Analisis, } \\
& \text { Perencanaan, Implementasi, dan } \\
& \text { Pengendalian. Jakarta: Salemba Empat. }
\end{aligned}
$$

Kotler, Philip, dan Kevin Keller. (2009). Manajemen Pemasaran. Edisi Kedua

Belas Jilid 1. Jakarta: PT. Indeks.

Nugroho, Setiadi. (2008). Perilaku Konsumen. Jakarta: Prenada Media.

Rangkuti, Freddy. (2009). Strategi Promosi yang Kreatif. Jakarta: PT.Gramedia.

Schiffman dan Kanuk. (2010). Perilaku Konsumen. Jakarta: Penerbit Indeks.

Simamora. (2008). Panduan Riset Perilaku Konsumen. Jakarta: Gramedia.

Sugiyono. (2012). Metode Penelitian Kuantitatif Kualitatif dan $R \& D$. Bandung: Alfabeta.
Sumarwan, Ujang. (2009). Perilaku Konsumen. Bogor: Ghalia Indonesia.

Sutisna. (2008). Perilaku Konsumen dan Komunikasi Pemasaran. Bandung: PT Remaja Rosda karya.

Tjiptono, Fandy. (2009). Strategi Bisnis. Yogyakarta: Pemasaran. Andi.
- How to cite this paper:

Rahmi, R., \& Nelly, N. (2018). Pengaruh Brand Image dan Sikap Konsumen Terhadap Ekuitas Merek Pada Produk Ija Kroeng di Kota Banda Aceh. Jurnal Humaniora, 2(2), 99-109. 